\title{
Evaluation of Reverse Osmosis Membranes in Concentration of Beetroot Peel Extract
}

\author{
Moh Moh Zin ${ }^{1 *}$, Edit Márki ${ }^{1 \dagger}$, Szilvia Bánvölgyi ${ }^{1}$ \\ 1 Department of Food Engineering, Faculty of Food Science, Szent István University, H-1118 Budapest, Ménesi út 44, Hungary \\ * Corresponding author, e-mail: zinlay.net.mm@gmail.com
}

Received: 30 September 2019, Accepted: 26 January 2020, Published online: 30 April 2020

\begin{abstract}
Recovery of valuable products from organic wastes with conventional extraction method plus modern separation technology is becoming popular in solid waste management. The major attention of this project was to test the efficiencies of two different types of reverse osmosis membranes (RO99 and X20) on juice concentration extracted from peel of beetroot which is "waste". The extractions of beetroot peel were completed using water and ethanol-water $(15 \mathrm{v} / \mathrm{v} \%)$ solvents at $22{ }^{\circ} \mathrm{C}$ for 60 minutes. The applied transmembrane pressure, temperature, and recirculation flow rate of membrane separation process were 40 bars, $30{ }^{\circ} \mathrm{C}$, and $400 \mathrm{~L} / \mathrm{h}$, respectively. Quantifications of valuable compounds were detected using spectrophotometer. The permeate flux profiles were investigated and lower permeate flux was experienced with RO99 compared to X20 in both methods. Additionally, from the aspect of efficiency, RO99 outstripped X20 membrane on concentration of some compounds such as betalains, and phenolic components. Betaxanthin, betacyanin, antioxidant and TPC contents in final retentates of RO99 membrane concentration were as follow: $292.47 \pm 1.93 \mathrm{mg} / \mathrm{L}, 499.03 \pm 1.3 \mathrm{mg} / \mathrm{L}, 1133.15 \pm 25.74 \mathrm{mg} / \mathrm{L}, 1243.96 \pm 106.56 \mathrm{mg} / \mathrm{L}$ (water solvent) and $337.26 \pm 4.31 \mathrm{mg} / \mathrm{L}$, $585.2 \pm 5.83 \mathrm{mg} / \mathrm{L}, 698.55 \pm 22.53 \mathrm{mg} / \mathrm{L}, 1268.87 \pm 48.69 \mathrm{mg} / \mathrm{L}$ (ethanol-water solvent), respectively. From this experiment, expectation can be made that membrane technology can widen its applications in food and pharmaceutical industries.
\end{abstract}

Keywords

beetroot peel, reverse osmosis, betalains, phenolic, antioxidant

\section{Introduction}

Utilizing wastes from food processing in proper way is somehow one of the solutions to environmental pollution problems. In addition, some of the waste parts of fruits and vegetables contain more valuable compounds than the other parts $[1,2]$.

Beetroot (Beta vulgaris) is one of the popular tropical vegetables in Europe because of its high constituent of natural colorant, which is betalain [3], and health-promoting antioxidant rich compounds especially phenolic [4]. Phenolic compounds are well known for their biochemical properties and basically extracted by alcohol-water mixtures [5]. Betalain is also rich in antioxidant capacity [6] and mainly composed of betacyanin (75-95\% of betanin which is responsible for red color) and betaxanthin (95\% of major yellow color giving vulgaxanthin-I) [7]. Being a water soluble compound, extraction of betalain can economically be performed by water. However, the disturbance of protein limits the usage of water as solvent and therefore, preferably, some kinds of solvents, for example, methanol and ethanol are employed [7]. Ethanol was chosen as the solvent in our project since, unlike methanol, no purification step is required.

The application of membrane technology (mostly ultrafiltration and microfiltration) to separate the various components from the feed stream has been receiving increased attention since the 1980s in different fields. Since that time, some researchers $[8,9]$ had already done the improvement of the extraction of betalain compounds with the aid of membrane separation. In recent times, this technology is a renaissance especially nanofiltration and reverse osmosis processes (occasionally combined with ultra and microfiltration as pre filtrations), not only for the isolation of different compounds but also for the concentration and/ or clarification of the fruit juices $[10,11]$.

Suitable membranes for different purposes of separation are chosen according to their pore sizes. Reverse osmosis membranes are basically used in water purification 
with the purpose of desalination. Even so, their applications in food and beverage industries are continuously expanding mostly in concentration of juices.

Tóth et al. [12] declared that membrane filtration is the only effective technology to separate materials possessing individual molecular weights so that we could extend their usages in various fields. The main purpose of this investigation was to evaluate the efficiency of membranes on concentration of valuable compounds from beetroot peel extracts.

\section{Materials and methods}

\subsection{Crude extract preparation}

Beetroots (Beta vulgaris L.) variety of Rhonda were purchased from local market. Primarily the beetroots were gently cleaned to remove foreign materials and peeled. The peels were then grounded using GM 200 pulverizer. Aqueous extraction was carried out as control in which the pulp (320 g) was mixed with distilled water $(3200 \mathrm{~mL})$ and extraction was achieved by single-batch-type extractor, which was designed with stirrer (LAUDA ECOLINE E100) and thermostat (YELLOWLINE BY IKA OST 20 DIGITAL), at $22{ }^{\circ} \mathrm{C}$ for 60 minutes based on our previous experiments. In case of ethanol-water solvent, $15 \mathrm{v} / \mathrm{v} \%$ ethanol solution was applied instead of distilled water. The measured $\mathrm{pH}$ of the crude extracts was in the range of 6 to 7.2. The final extracts were stored under freeze condition until membrane separation experiments.

\subsection{Membrane separation}

RO membranes of low fouling type Trisep X20 advanced composite membrane (Lenntech) and thin film composite Alfa Laval RO99 membrane with active surface areas of $0.18 \mathrm{~m}^{2}$ were applied. Cross-flow filtration process was performed by DDS Filtration Equipment (LAB 20-0.72, Denmark). The average inlet and outlet transmembrane pressure was 40 bars and recirculation flow rate was $400 \mathrm{~L} / \mathrm{h}$ maintaining the temperature of the stream at $30^{\circ} \mathrm{C}$. During the concentration, the time required to collect each $100 \mathrm{~mL}$ of filtrate was recorded and the sample collections were performed at every $500 \mathrm{~mL}$ of permeates. After separations, the analytical measurements were carried out.

Pure water flux measurements were performed before and after concentration step in order to estimate membrane resistance and fouling resistance. After the concentration process, distilled water was used for rinsing and removing the polarization layer completely. According to Darcy's Law, permeate flux $J\left(\mathrm{~m}^{3} /\left(\mathrm{m}^{2} \times \mathrm{s}\right)\right)$ for pure water can simply be demonstrated as:
$J=\frac{T M P}{\mu \times R_{m}}$,

where TMP means the applied transmembrane pressure difference $(\mathrm{Pa})$ as driving force; $\mu$ is the dynamic viscosity of permeate $(\mathrm{Pa} \times \mathrm{s}) ; R_{m}$ represents membrane resistance $(1 / \mathrm{m})$ to mass transfer [13].

Subsequently, membrane resistance $\left(R_{m}\right)$ and fouling resistance $\left(R_{f}\right)$ can be derived from Darcy's Law:

$R_{m}=\frac{1}{\mu \times a_{1}}$

$R_{f}=\frac{1}{\mu \times a_{2}}-R_{m}$,

where $a_{1}$ and $a_{2}$ means slope of pure water flux curves before and after measurement versus transmembrane pressure difference.

The permeate flux $\left(\mathrm{L} /\left(\mathrm{m}^{2} \times \mathrm{h}\right)\right)$ of the sample was simply calculated from volume of filtrate $\Delta V(\mathrm{~L})$ divided by $\Delta t(\mathrm{~h})$, the time required to collect the filtrate, and active surface area of membrane $A_{m}\left(\mathrm{~m}^{2}\right)$ [14].

$J_{x}=\frac{\Delta V}{A_{m} \times \Delta t}$

According to the research of Bánvölgyi et al. [15], Volume Reduction Ratio (VRR) was approved by feed volume $V_{0}\left(\mathrm{~m}^{3}\right)$ and volume of retentate $V_{R}\left(\mathrm{~m}^{3}\right)$ or volume of permeate $V_{P}\left(\mathrm{~m}^{3}\right)$ following the Eq. (5);

$\operatorname{VRR}=\frac{V_{0}}{V_{R}}=\frac{V_{0}}{V_{0}-V_{P}}$.

Based on the concentrations of permeate $C_{p}(\mathrm{mg} / \mathrm{L})$ and retentate $C_{R}(\mathrm{mg} / \mathrm{L})$, retention (\%) can be estimated as follows (Eq. (6)) [15]:

$R=\left(1-\frac{C_{P}}{C_{R}}\right) \times 100$.

\subsection{Spectrophotometric analysis}

Spectronic Genesys 5 Spectrophotometer (MILTON ROY, U.S.A.) was applied for the quantification of betalain compounds. The colors were detected as absorption at individual wavelengths of $480 \mathrm{~nm}$ for betaxanthin [16] and $535 \mathrm{~nm}$ for betacyanin [17]. The appropriate dilution was done for each sample and the concentrations of the respective betalain compounds were calculated using Eq. (7):

$B C=\frac{A \times M W \times D F \times 1000}{\varepsilon \times L}[\mathrm{mg} / \mathrm{L}]$,

where $A$ is the absorbance; $M W$ is the molecular weight ( $\mathrm{g} / \mathrm{mol}) ; D F$ is the dilution factor; $\varepsilon$ is the molar extinction coefficient $(\mathrm{L} /(\mathrm{mol} \times \mathrm{cm}))$ and $L$ is the path length $(\mathrm{cm})$. 
For quantification of betaxanthin and betacyanin, molar extinction coefficients and molecular weights for respective compounds i.e. betaxanthin $(\varepsilon=48,000 \mathrm{~L} /(\mathrm{mol} \times \mathrm{cm})$ and $M W=308 \mathrm{~g} / \mathrm{mol})$, and for betacyanin $(\varepsilon=60,000 \mathrm{~L} /(\mathrm{mol} \times \mathrm{cm})$ and $M W=550 \mathrm{~g} / \mathrm{mol}$ ) were applied [18].

Additionally, spectrophotometric method was applied for Total Phenolic Compound (TPC, $760 \mathrm{~nm}$ ) and antioxidant (593 nm) assays. TPC contents of each sample were analyzed according to Folin-Ciocalteu method [19] following employed procedure. The sample solution $(20 \mu \mathrm{L})$ was mixed with $1250 \mu \mathrm{L}$ of Folin reagent and $230 \mu \mathrm{L}$ of methanol-distilled water solution. After exactly 1 minute, $1000 \mu \mathrm{L}$ of sodium carbonate solution $(0.7 \mathrm{M})$ was added to the sample solution [20]. The mixture was then put in thermal bath which maintained the temperature at $50{ }^{\circ} \mathrm{C}$ and absorbance measurement was carried out at $760 \mathrm{~nm}$ after 5 minutes of incubation. The calibration was done by using $(0.3 \mathrm{mM})$ gallic acid as standard and gave $R^{2}$ value of 0.99. TPC was calculated according to the Eq. (8):

$$
\mathrm{TPC}=\frac{A \times 2500 \times D F}{S \times a_{3}}\left[\frac{\mathrm{mg} \mathrm{GAE}}{\mathrm{L}}\right],
$$

whereby $A$ is the measured absorbance; $S$ is the amount of sample $(\mu \mathrm{L}) ; a_{3}$ is the slope of calibration curve; $D F$ is the dilution factor.

Ferric Reducing Antioxidant Power (FRAP) method was applied to investigate the antioxidant capacity in reference to Benzie and Devaki [21]. FRAP reagent was prepared with $250 \mu \mathrm{L}$ of acetate buffer solution $(\mathrm{pH}=3.6), 25 \mu \mathrm{L}$ of ferric chloride solution (30 mM), and $25 \mu \mathrm{L}$ of TPTZ solution $(10 \mathrm{mM}$ dissolved in $40 \mathrm{mM} \mathrm{HCl})$. FRAP reagent $(1500 \mu \mathrm{L})$ was mixed with $(30 \mu \mathrm{L})$ distilled water followed by sample solution $(20 \mu \mathrm{L})$ and incubated for 5 minutes at room temperature in the dark. After exactly 5 minutes, the absorbance measurement was performed at $593 \mathrm{~nm}$ on Genesys 5 UV-Visible spectrophotometer. The calibration was realized with ascorbic acid (10 mM) instead of sample solution and expressed as ascorbic acid equivalent and $R^{2}$ value of 0.99 was depicted from the calibration curve. The calculation was done using the Eq. (9);

$$
A C=\frac{A \times 1550 \times D F}{S \times a_{4}}\left[\frac{\mathrm{mg} \mathrm{ASE}}{\mathrm{L}}\right],
$$

where $A$ is the absorbance; $S$ is the amount of sample $(\mu \mathrm{L})$; $a_{4}$ is the slope of calibration curve; $D F$ is the dilution factor. All measurements were triplicated under the same conditions. Data was evaluated by performing significant test based on variance analysis model through Microsoft Excel 2010 software.

\section{Results and discussions}

\subsection{Statistical analysis}

Results of statistical evaluation proved that significant level $(\alpha)$ for each sample is quite satisfactory $(99.99 \%$ significant level) $p$-value less than 0.001 .

\subsubsection{Color compounds concentration}

Quantification of betalain compounds in initial feeds, retentates and permeates $(500 \mathrm{~mL}, 1000 \mathrm{~mL}, 1500 \mathrm{~mL}$, $2000 \mathrm{~mL}$, and final volume) collected during concentration processes with two types of reverse osmosis membranes (RO99 and X20) were conducted by spectrophotometric analysis. The resulting betaxanthin and betacyanin contents in each sample were shown in Tables 1 and 2. As we can

\begin{tabular}{|c|c|c|c|c|c|}
\hline Solvent & Sample & Betaxanthin (mg/L) & Betacyanin $(\mathrm{mg} / \mathrm{L})$ & $\mathrm{TPC}(\mathrm{mg} / \mathrm{L})$ & Antioxidant (mg/L) \\
\hline \multirow{6}{*}{ 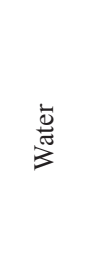 } & Initial & $75.46 \pm 0.45$ & $117.33 \pm 0.32$ & $187.95 \pm 18.54$ & $107.7 \pm 13.05$ \\
\hline & $R(500 \mathrm{~mL})$ & $89.06 \pm 1.3$ & $142.27 \pm 0.65$ & $299.67 \pm 22.91$ & $138.8 \pm 41.83$ \\
\hline & $R(1000 \mathrm{~mL})$ & $130.13 \pm 1.93$ & $216.33 \pm 1.21$ & $358.54 \pm 17.3$ & $170.65 \pm 3.22$ \\
\hline & $R(1500 \mathrm{~mL})$ & $182.75 \pm 0.81$ & $309.47 \pm 0.7$ & $551.03 \pm 11.4$ & $195.68 \pm 12.04$ \\
\hline & $R(2000 \mathrm{~mL})$ & $249.22 \pm 1.34$ & $419.65 \pm 0.65$ & $868.06 \pm 26.83$ & $359.51 \pm 25.74$ \\
\hline & Final & $292.47 \pm 1.93$ & $499.03 \pm 1.3$ & $1243.96 \pm 106.56$ & $1133.15 \pm 25.74$ \\
\hline \multirow{6}{*}{ 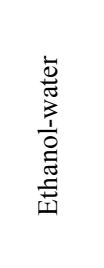 } & Initial & $87.27 \pm 0.93$ & $159.87 \pm 0.7$ & $332.13 \pm 24.21$ & $173.08 \pm 2.67$ \\
\hline & $R(500 \mathrm{~mL})$ & $108.06 \pm 3.63$ & $196.17 \pm 6.16$ & $370.62 \pm 10.21$ & $121.35 \pm 6.95$ \\
\hline & $R(1000 \mathrm{~mL})$ & $127.05 \pm 1.45$ & $232.1 \pm 0.65$ & $488.38 \pm 2.61$ & $133.49 \pm 22.45$ \\
\hline & $R(1500 \mathrm{~mL})$ & $180.18 \pm 2.95$ & $329.63 \pm 2.92$ & $754.08 \pm 31.7$ & $289.73 \pm 14.63$ \\
\hline & $R(2000 \mathrm{~mL})$ & $304.41 \pm 2.95$ & $551.47 \pm 4.54$ & $1005.44 \pm 78.57$ & $648.49 \pm 74.01$ \\
\hline & Final & $337.26 \pm 4.31$ & $585.2 \pm 5.83$ & $1268.87 \pm 48.69$ & $698.55 \pm 22.53$ \\
\hline
\end{tabular}

Table 1 Betalains, total phenolic compounds, and antioxidant contents in crudes and retentates of RO99 type reverse osmosis membrane separation 
Table 2 Betalains, total phenolic compounds, and antioxidant contents in crudes and retentates of X20 type reverse osmosis membrane separation

\begin{tabular}{|c|c|c|c|c|c|}
\hline Solvent & Sample & Betaxanthin $(\mathrm{mg} / \mathrm{L})$ & Betacyanin (mg/L) & $\mathrm{TPC}(\mathrm{mg} / \mathrm{L})$ & Antioxidant (mg/L) \\
\hline \multirow{6}{*}{$\frac{\bar{\Delta}}{\vec{J}}$} & Initial & $84.44 \pm 0.45$ & $167.93 \pm 1.3$ & $188.43 \pm 2.81$ & $126.99 \pm 13.9$ \\
\hline & $R(500 \mathrm{~mL})$ & $52.36 \pm 2.22$ & $101.93 \pm 0.32$ & $133.20 \pm 17.23$ & $344.44 \pm 17.81$ \\
\hline & $R(1000 \mathrm{~mL})$ & $67.5 \pm 1.13$ & $129.07 \pm 0.97$ & $539.31 \pm 0.00$ & $469.26 \pm 61.57$ \\
\hline & $R(1500 \mathrm{~mL})$ & $112.93 \pm 1.13$ & $215.6 \pm 1.3$ & $726.12 \pm 0.00$ & $1175.56 \pm 30.79$ \\
\hline & $R(2000 \mathrm{~mL})$ & $190.96 \pm 1.13$ & $357.87 \pm 3.31$ & $969.79 \pm 96.49$ & $1274.73 \pm 5.13$ \\
\hline & Final & $253.33 \pm 1.52$ & $450.27 \pm 2.07$ & $1003.9 \pm 13.78$ & $2428.53 \pm 35.92$ \\
\hline \multirow{6}{*}{ 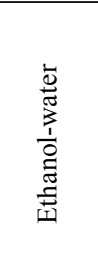 } & Initial & $94.71 \pm 0.19$ & $192.13 \pm 0.00$ & $214.43 \pm 34.46$ & $424.02 \pm 17.84$ \\
\hline & $R(500 \mathrm{~mL})$ & $66.99 \pm 1.13$ & $125.77 \pm 0.92$ & $217.67 \pm 17.23$ & $420.88 \pm 37.71$ \\
\hline & $R(1000 \mathrm{~mL})$ & $84.44 \pm 1.77$ & $154.73 \pm 2.8$ & $471.09 \pm 10.34$ & $440.23 \pm 10.26$ \\
\hline & $R(1500 \mathrm{~mL})$ & $120.38 \pm 1.59$ & $219.27 \pm 0.97$ & $492.20 \pm 48.24$ & $761.94 \pm 87.23$ \\
\hline & $R(2000 \mathrm{~mL})$ & $136.55 \pm 0.00$ & $261.8 \pm 0.00$ & $718.81 \pm 106.82$ & $1148.95 \pm 20.52$ \\
\hline & Final & $366.78 \pm 0.00$ & $586.3 \pm 4.54$ & $869.88 \pm 120.61$ & $1925.41 \pm 118.02$ \\
\hline
\end{tabular}

see in Table 1, betaxanthin content of initial feeds for RO99 membrane concentrations were $75.46 \pm 0.45 \mathrm{mg} / \mathrm{L}$ (water solvent) and $87.27 \pm 0.93 \mathrm{mg} / \mathrm{L}$ (ethanol-water solvent).

Concentration of betaxanthin compound in both extracts increased continuously in each sample and final retentates contained up to $292.47 \pm 1.93 \mathrm{mg} / \mathrm{L}$ and $337.26 \pm 4.31 \mathrm{mg} / \mathrm{L}$ in water and ethanol-water extracts, individually. Betalain compounds content in each sample during RO filtrations were depicted in Figs. 1 and 2 in the function of VRR. Concentration ratios $\left(\mathrm{C}_{\mathrm{R}} / \mathrm{C}_{0}\right)$ of betaxanthin in final retentates (RO99) were almost the same for both water and ethanol-water extracts as displayed in Fig. 1.

According to Fig. 2, the trend of betacyanin concentration ratio for water extract exceeded ethanol-water data. This means that RO99 membrane had greater effect on concentration of water extract. The amount of betacyanin measured in water and ethanol-water extracts were $117.33 \pm 0.32 \mathrm{mg} / \mathrm{L}$ (initial), $499.03 \pm 1.3 \mathrm{mg} / \mathrm{L}$ (final), and $159.87 \pm 0.7 \mathrm{mg} / \mathrm{L}$ (initial), $585.2 \pm 5.83 \mathrm{mg} / \mathrm{L}$ (final), respectively.

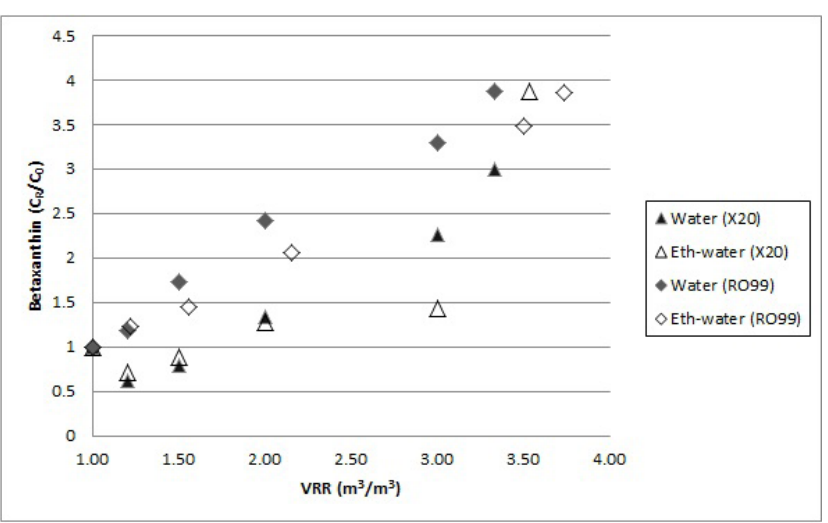

Fig. 1 Variation of betaxanthin color compound content with VRR during concentration by RO99 and X20 reverse osmosis membranes

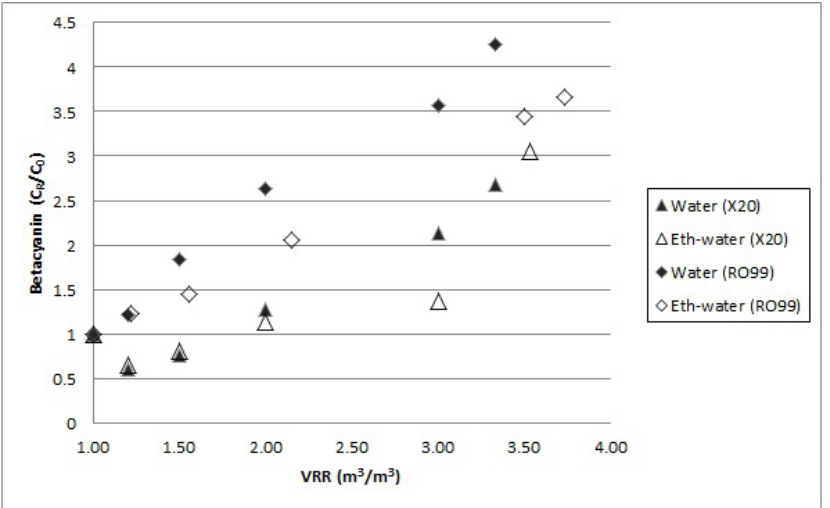

Fig. 2 Variation of betacyanin color compound content with VRR during concentration by RO99 and X20 reverse osmosis membranes

In the case of X20 type RO filtrations, the initial amounts of betalain compounds in water extract were $84.44 \pm 0.45 \mathrm{mg} / \mathrm{L}$ (betaxanthin) and $167.93 \pm 1.3 \mathrm{mg} / \mathrm{L}$ (betacyanin) while aqueous ethanol extract contains $94.71 \pm 0.19 \mathrm{mg} / \mathrm{L}$ of betaxanthin and $192.13 \pm 0.00 \mathrm{mg} / \mathrm{L}$ of betacyanin. It was noted that these feed concentrations outweighed $500 \mathrm{~mL}$ and $1000 \mathrm{~mL}$ samples as shown in Table 2.

The possible explanation to this might have been that some amount of water left in the dead space of the pipes of the equipment and caused the dilution of the feed when separation process was started. The amount of betalains went up later on against crude extracts and final concentrates reached of betaxanthin $253.33 \pm 1.52 \mathrm{mg} / \mathrm{L}$ and betacyanin $450.27 \pm 2.07 \mathrm{mg} / \mathrm{L}$ in water extract whilst the final concentrates of ethanol-water extract exhibited $366.78 \pm 0.00 \mathrm{mg} / \mathrm{L}$ and $586.3 \pm 4.54 \mathrm{mg} / \mathrm{L}$ of betaxanthin and betacyanin, respectively.

In overall point of view, the greater amount of both color compounds was maintained in aqueous ethanol extracts. It proved that $15 \mathrm{v} / \mathrm{v} \%$ aqueous ethanol solvent 
affected more on the extraction of color compounds than water however these compounds are water soluble [22]. Besides, the amount of betacyanin extracted was exhibited to be double of betaxanthin concentration in all cases. The possible explanation is due to the less sensitive property of betacyanin to process conditions than betaxanthin. The concentration ratio of betacyanin was the superiority among the final extracts meaning that the membranes concentrated more amount of betacyanin than betaxanthin. It is rational since betacyanin has larger molecular weight $(550 \mathrm{~g} / \mathrm{mol})$ than betaxanthin $(308 \mathrm{~g} / \mathrm{mol})$ [23].

\subsection{Total Phenolic Compounds (TPC)}

As regard the first, the superior amount of phenolic compounds were beheld in ethanol-water crude extracts $(332.13 \pm 24.21 \mathrm{mg} / \mathrm{L}$ and $214.43 \pm 34.46 \mathrm{mg} / \mathrm{L})$ as against water extract $(187.95 \pm 18.54 \mathrm{mg} / \mathrm{L}$ and $188.43 \pm 2.81 \mathrm{mg} / \mathrm{L})$ in RO99 and X20 feeds (Tables 1 and 2). Being the batch type extraction and filtration processes, the rationale could be that the profiles of the beetroot peel extracts depended upon the variety and maturation stage of the raw beetroots as reported by Bucur et al. [24]. Nevertheless the efficiency of membranes on concentration of this compound was seen to be higher in water extracts according to Fig. 3.

Furthermore, less amount of TPC was found in final extract of ethanol-water $(869.88 \pm 120.61 \mathrm{mg} / \mathrm{L})$ with regard to water extract $(1003.9 \pm 13.78 \mathrm{mg} / \mathrm{L})$ in X20 membrane concentrations. In contrast, large amounts of TPC were retained in both final extracts of RO99 filtrations with quite similar amounts as $1243.96 \pm 106.56 \mathrm{mg} / \mathrm{L}$ (water) and $1268.87 \pm 48.69 \mathrm{mg} / \mathrm{L}$ (ethanol-water), separately.

The trends acted almost the same way in all concentration processes. Concentration ratio of TPC became higher in each filtrate along with expanding VRR than

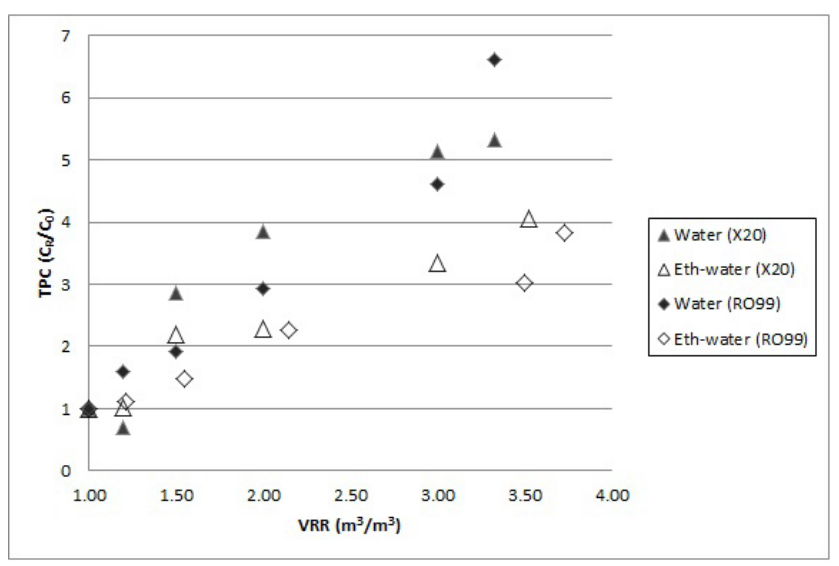

Fig. 3 Total phenolic compound content with VRR during concentration by RO99 and X20 reverse osmosis membranes initial ones except the case of water extract (X20) where TPC content was a bit nether in $500 \mathrm{~mL}$ sample than in the feed. It might have been the same possible explanation with betalain compounds separation as discussed earlier.

\subsection{Antioxidant assay}

The antioxidant contents in ethanol-water crude extracts, the feeds for RO99 and X20 membrane filtrations, were recorded as $173.08 \pm 2.67 \mathrm{mg} / \mathrm{L}$ and $424.02 \pm 17.84 \mathrm{mg} / \mathrm{L}$ howbeit the water could extract only $107.7 \pm 13.05 \mathrm{mg} / \mathrm{L}$ and $126.99 \pm 13.9 \mathrm{mg} / \mathrm{L}$, respectively (Tables 1 and 2). As we mentioned earlier, specific properties of raw materials could be responsible for these differences in value albeit size, maturity, and ripeness were basic parameters for the beetroot selection. As we can see in Tables 1 and 2, ethanol-water extracts contain less amount of antioxidant in final retentates than water extract, with $698.55 \pm 22.53 \mathrm{mg} / \mathrm{L}$ and $1925.41 \pm 118.02 \mathrm{mg} / \mathrm{L}$ as opposed to $1133.15 \pm 25.74 \mathrm{mg} / \mathrm{L}$ and $2428.53 \pm 35.92 \mathrm{mg} / \mathrm{L}$ for RO99 and X20 membranes, individually. Fig. 4 represents antioxidant components in each sample varied with VRR.

From the Fig. 4, it was noticed that more antioxidant was concentrated with increasing Volume Reduction Ratio (VRR) in all processes. The trend of concentration ratio of water extract (X20) was astray from others and even overtook drastically the concentration trends of RO99. The huge amount of antioxidant in the final concentrates of water extracts implies that the membranes were quite effective on concentration of different types of water soluble compounds which exhibit antioxidant property. This is reasonable as betalain and phenolic compounds are highly correlated with antioxidant capacity as reported by Bucur et al. [24] and Kavalcová et al. [4].

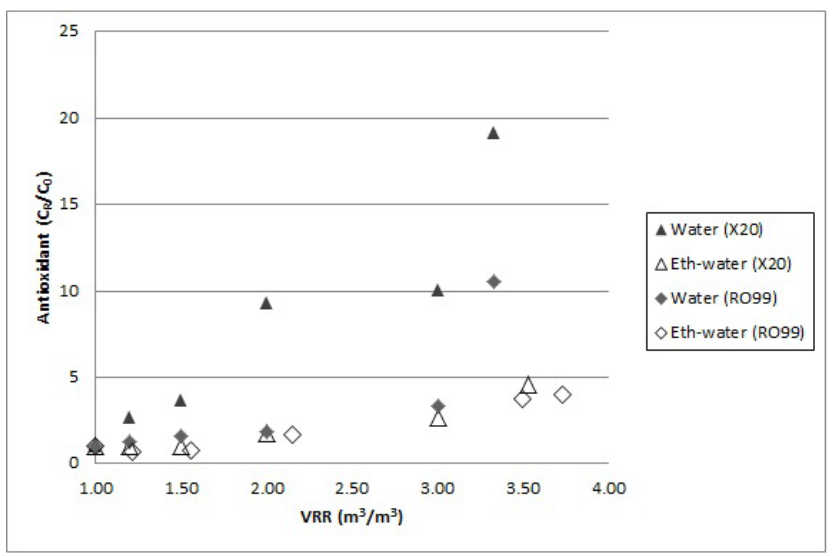

Fig. 4 Variation of antioxidant capacity in each sample with VRR during concentration by RO99 and X20 reverse osmosis membranes 


\subsection{Permeate Flux Measurement}

Flux behavior for reverse osmosis filtration of beetroot peel extracts with membrane type of RO99 in the function of volume reduction ratio is shown in Fig. 5. Both water and ethanol-water extracts were fed to the system at 40 bars of transmembrane pressure adjusting the stream temperature at $30{ }^{\circ} \mathrm{C}$. As depicted in Fig. 5, the permeate flux of water extract behaved obviously different from of ethanol-water. Initially, the fluxes of both extracts were tapered off until around VRR 2. That fluxes behavior shows the initial accumulation of the compounds on and/or in the membranes which causes membrane fouling and concentration polarization. The same observation was reported by Couto et al. [25]. Moreover, the flux of ethanol-water reached $16.9 \mathrm{~L} /\left(\mathrm{m}^{2} \times \mathrm{h}\right)$ at VRR $=3.73$ after about 35 minutes of concentration time whilst the permeate flux of water extract could reach $\mathrm{VRR}=3.33$ with $41.27 \mathrm{~L} /\left(\mathrm{m}^{2} \times \mathrm{h}\right)$ permeate flux in very short time (12 minutes). Due to their difference in polarity, ethanol-water solvent could extract some more compounds than only water leading to formation of polarized layer. Nevertheless, physical property of water such as dielectric constant and molecular weight, which exceeded alcoholic solvent, could attribute to elevated flux in water extract as well [26].

Fig. 6 reveals the permeate flux profile of beetroot peel extracts with X20 membrane type filtration. As we can see from Fig. 6, reduction of permeate flux was manifested with elevated process time at fixed transmembrane pressure (40 bars). Like in the case of RO99, the concentration process of water extract was quite faster than ethanol-water extract. It took only 15 minutes for water extract to reach $\mathrm{VRR}=3.33$ whereas, for ethanol-water, one hour time was necessary to reach the same level of VRR. Besides, the

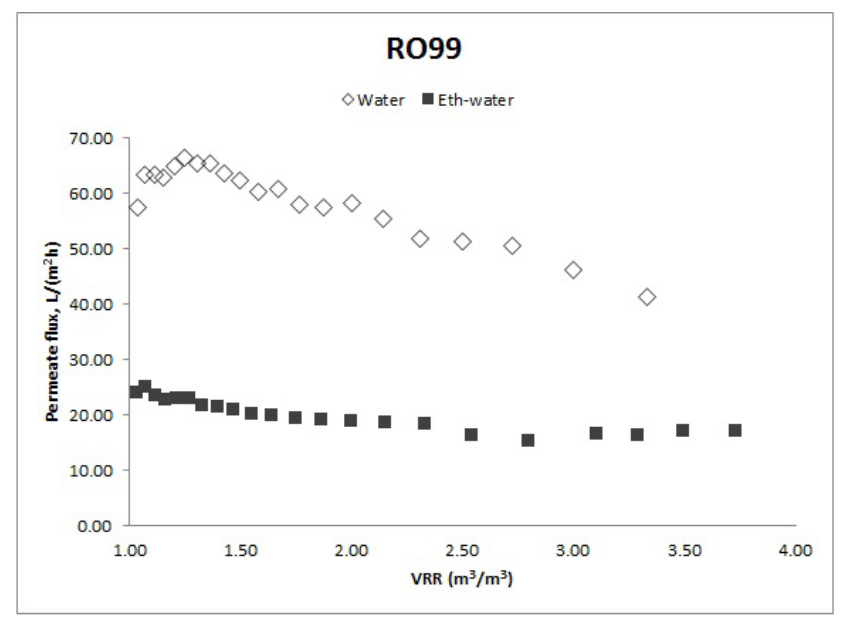

Fig. 5 Permeate flux values changing with VRR during the concentration process by reverse osmosis type RO99

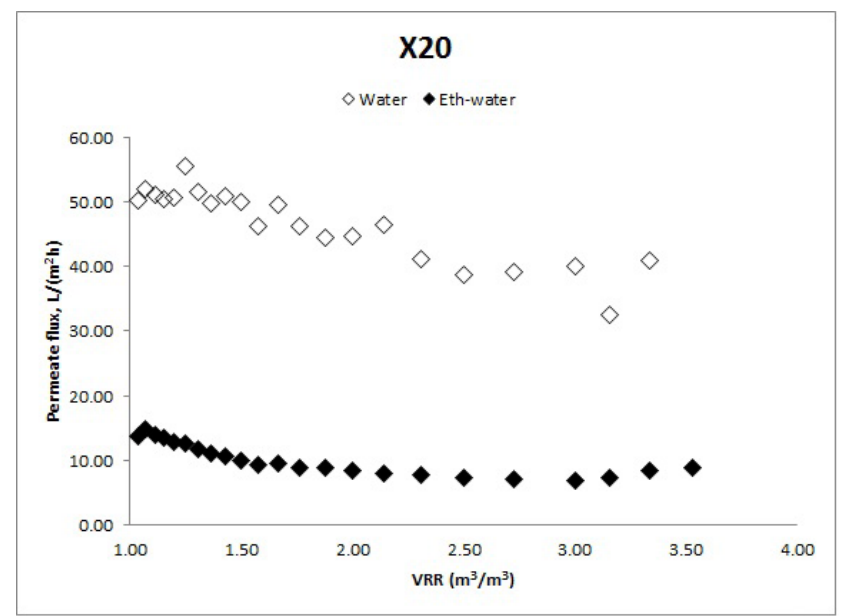

Fig. 6 Changes in permeate flux values with VRR during the concentration process by reverse osmosis type X20

final VRR 3.53 was achieved with ethanol-water extract after 1 hour and 12 minutes of separation time. The accumulation of foulants, cake formation, pore plugging on/in the membrane layers might be the responsible ones for the resistance to permeation [13].

From pure water flux measurements after concentration process, fouling resistances of the membranes were calculated as depicted in Fig. 7. It can be assumed that concentration of ethanol-water extract by RO99 membrane was more effective than of water extract without interfering membrane feature, therefore significant diminished in fouling resistance was demonstrated compared to water extract. Being regarded as non-porous, reverse osmosis membranes are somehow high in fouling propensity on account of cake layer formation [27]. Since we used low fouling resistance type, fouling of X20 type RO membrane was negligible.

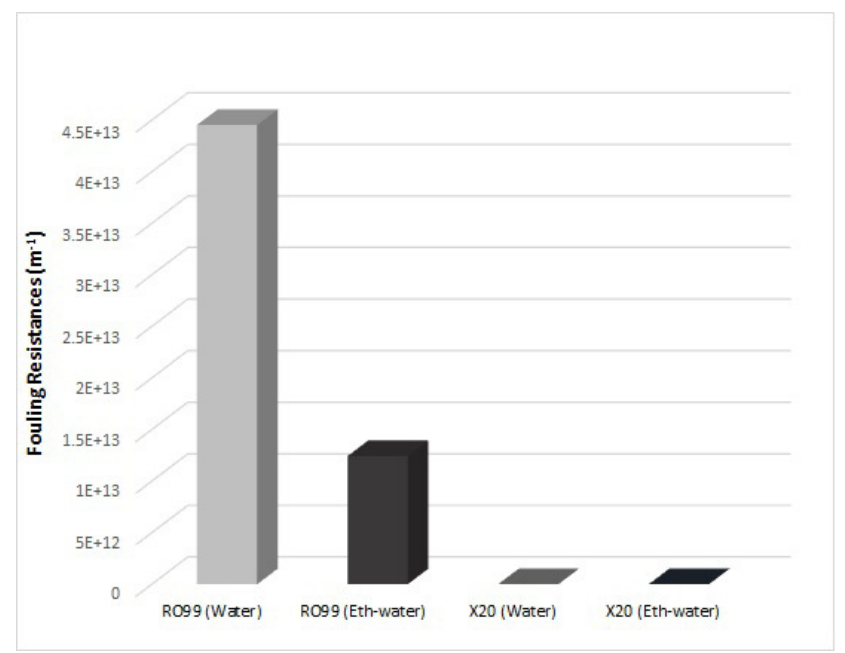

Fig. 7 Fouling resistances of RO99 and X20 membranes 
Retention percentages were calculated from the concentration data of final permeates and retentates (Fig. 8) In RO99 membrane concentration processes, betaxanthin and betacyanin retentions in both water and ethanol-water extracts were amounting from $96 \%$ to $99 \%$. In case of X20 membrane, retentions of betaxanthin and betacyanin were deducted about $6 \%$ and $9 \%$ in water extract, and $17 \%$ and $23 \%$ in ethanol-water extract as opposed to RO99. Since permeates of each membrane did not show the presence of TPC and antioxidant contents, retention was supposed to be $99.99 \%$ for those compounds not only in water extract but also in ethanol-water.

\section{Conclusion}

Based on all results, concentration level accomplished by RO99 was superior to X20. Retentions of antioxidant and total phenolic compounds reached $99.99 \%$ in both types of extract solutions and betalain retentions were over $95 \%$ as well. Therefore, it is estimated that the filtrations of those valuable compounds with RO99 membrane were fully performed. In our work, extraction process was carried out with only 1:10 ratio of peel-to-solvent. In order to improve the yield of valuable compounds, further investigations with improvements in extraction step are necessary. In accordance with our experimental results, the conclusion comes up with that membrane technology can be applied effectively in concentration or separation of valuable compounds from vegetable wastes.

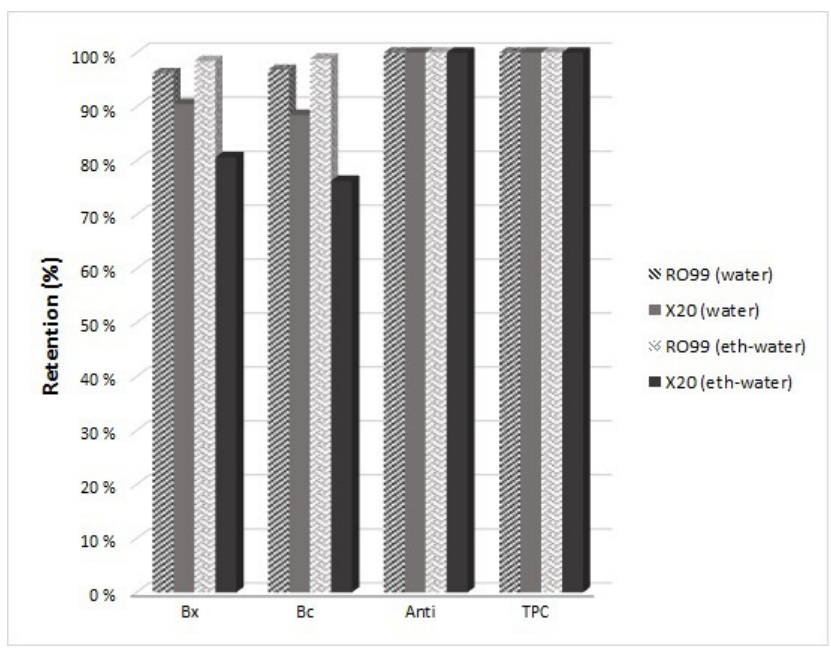

Fig. 8 Retention percentages of RO99 and X20 membranes

\section{Acknowledgements}

The authors acknowledged the Ministry of Innovation and Technology within framework of the Higher Education Institutional Excellence Program (NKFIH-1159-6/2019), and the European Union and the European Social Fund (grant agreement no. EFOP-3.6.3-VEKOP-16-2017-00005), the Tempus Public Foundation under the Stipendium Hungaricum Scholarship Program for their financial support to our project.

\section{Nomenclature}

$\Delta t \quad$ time required to collect the filtrate (h)

$\Delta V \quad$ volume of filtrate (L)

$A \quad$ sample absorbance

$A_{m} \quad$ active surface area of membrane $\left(\mathrm{m}^{2}\right)$

$a_{1}$ slope of pure water flux curve before the concentration

$a_{2} \quad$ slope of pure water flux curve after the concentration

$a_{3} \quad$ slope of TPC calibration curve

$a_{4} \quad$ slope of $A C$ calibration curve

$A C$ antioxidant capacity $(\mathrm{mg} / \mathrm{L})$

$\mathrm{Bc}$ betacyanin compounds concentration $(\mathrm{mg} / \mathrm{L})$

$B C \quad$ betalain compounds concentration $(\mathrm{mg} / \mathrm{L})$

$\mathrm{Bx}$ betaxanthin compounds concentration $(\mathrm{mg} / \mathrm{L})$

$C_{0} \quad$ feed concentration $(\mathrm{mg} / \mathrm{L})$

$C_{p} \quad$ concentration of permeate $(\mathrm{mg} / \mathrm{L})$

$C_{R} \quad$ concentration of retentate $(\mathrm{mg} / \mathrm{L})$

DF dilution factor

$J \quad$ permeate flux of pure water $\left(\mathrm{m}^{3} /\left(\mathrm{m}^{2} \times \mathrm{s}\right)\right)$

$J_{x} \quad$ permeate flux of the sample $\left(\mathrm{L} /\left(\mathrm{m}^{2} \times \mathrm{h}\right)\right)$

$L \quad$ path length (cm)

$M W \quad$ molecular weight $(\mathrm{g} / \mathrm{mol})$

$R_{m} \quad$ membrane resistance $(1 / \mathrm{m})$

$R_{f} \quad$ fouling resistance $(1 / \mathrm{m})$

$S \quad$ amount of sample $(\mu \mathrm{L})$

TMP applied transmembrane pressure difference $(\mathrm{Pa})$

TPC concentration of total phenolic compounds $(\mathrm{mg} / \mathrm{L})$

$V_{0} \quad$ feed volume $\left(\mathrm{m}^{3}\right)$

$V_{P} \quad$ volume of permeate $\left(\mathrm{m}^{3}\right)$

$V_{R} \quad$ volume of retentate $\left(\mathrm{m}^{3}\right)$

$\mu \quad$ dynamic viscosity of permeate $(\mathrm{Pa} \times \mathrm{s})$

$\varepsilon \quad$ molar extinction coefficient $(\mathrm{L} /(\mathrm{mol} \times \mathrm{cm}))$ 


\section{References}

[1] Osorio-Esquivel, O., Ortiz-Moreno, A., Álvarez, V. B., DorantesÁlvarez, L., Giusti, M. M. "Phenolics, betacyanins and antioxidant activity in Opuntia joconostle fruits", Food Research International, 44(7), pp. 2160-2168, 2011.

https://doi.org/10.1016/j.foodres.2011.02.011

[2] Sawicki, T., Bączek, N., Wiczkowski, W. "Betalain profile, content and antioxidant capacity of red beetroot dependent on the genotype and root part", Journal of Functional Foods, 27, pp. 249-261, 2016. https://doi.org/10.1016/j.jff.2016.09.004

[3] Choo, W. S. "Betalains: Application in Functional Foods", In: Mérillon, J. M., Ramawat, K. G. (eds.) Bioactive Molecules in Food, Springer, Cham, Switzerland, 2019, pp. 1471-1498.

https://doi.org/10.1007/978-3-319-78030-6_38

[4] Kavalcová, P., Bystrická, J., Tomáš, J., Karovičová, J., Kovarovič, J., Lenková, M. "The content of total polyphenols and antioxidant activity in red beetroot", Potravinarstvo: Slovak Journal of Food Sciences, 9(1), pp. 77-83, 2015. https://doi.org/10.5219/441

[5] Murkovic, M. "Phenolic Compounds", In: Trugo, L., Finglas, P. M. (eds.) Encyclopedia of Food Sciences and Nutrition, Academic Press, Oxford, UK, 2003, pp. 4507-4514. https://doi.org/10.1016/B0-12-227055-X/00914-7

[6] Sawicki, T., Wiczkowski, W. "The effects of boiling and fermentation on betalain profiles and antioxidant capacities of red beetroot products", Food Chemistry, 259, pp. 292-303, 2018.

https://doi.org/10.1016/j.foodchem.2018.03.143

[7] Cai, Y. Z., Sun, M., Corke, H. "Characterization and application of betalain pigments from plants of the Amaranthaceae", Trends in Food Science \& Technology, 16(9), pp. 370-376, 2005. https://doi.org/10.1016/j.tifs.2005.03.020

[8] Bayindirli, A., Yildiz, F., Özilgen, M. "Modelling of Sequential Batch Ultrafiltration of Red Beet Extract", Journal of Food Science, 53(5), pp. 1418-1421, 1988.

https://doi.org/10.1111/j.1365-2621.1988.tb09290.x

[9] Lee, Y. N., Wiley, R. C., Sheu, M. J., Schlimme, D. V. "Purification and Concentration of Betalaines by Ultrafiltration and Reverse Osmosis", Journal of Food Science, 47(2), pp. 465-471, 1982. https://doi.org/10.1111/j.1365-2621.1982.tb10105.x

[10] Ghosh, P., Pradhan, R. C., Mishra, S., Rout, P. K. "Quantification and Concentration of Anthocyanidin from Indian Blackberry (Jamun) by Combination of Ultra- and Nano-filtrations", Food and Bioprocess Technology, 11(12), pp. 2194-2203, 2018. https://doi.org/10.1007/s11947-018-2176-4

[11] Mereddy, R., Chan, A., Fanning, K., Nirmal, N., Sultanbawa, Y. "Betalain rich functional extract with reduced salts and nitrate content from red beetroot (Beta vulgaris L.) using membrane separation technology", Food Chemistry, 215, pp. 311-317, 2017. https://doi.org/10.1016/j.foodchem.2016.07.132

[12] Tóth, A. J., Gergely, F., Mizsey, P. "Physicochemical treatment of pharmaceutical process wastewater: distillation and membrane processes", Periodica Polytechnica Chemical Engineering, 55(2), pp. 59-67, 2011.

https://doi.org/10.3311/pp.ch.2011-2.03
[13] Miller, D. J., Kasemset, S., Paul, D. R., Freeman, B. D. "Comparison of membrane fouling at constant flux and constant transmembrane pressure conditions", Journal of Membrane Science, 454, pp. 505-515, 2014. https://doi.org/10.1016/j.memsci.2013.12.027

[14] Liu, M., Lü, Z., Chen, Z., Yu, S., Gao, C. "Comparison of reverse osmosis and nanofiltration membranes in the treatment of biologically treated textile effluent for water reuse", Desalination, 281, pp. 372-378, 2011.

https://doi.org/10.1016/j.desal.2011.08.023

[15] Bánvölgyi, S., Horváth, S., Stefanovits-Bányai, É., BékássyMolnár, E., Vatai, G. "Integrated membrane process for blackcurrant (Ribes nigrum L.) juice concentration", Desalination, 241(1-3), pp. 281-287, 2009.

https://doi.org/10.1016/j.desal.2007.11.088

[16] Kushwaha, R., Kumar, V., Vyas, G., Kaur, J. "Optimization of Different Variable for Eco-friendly Extraction of Betalains and Phytochemicals from Beetroot Pomace", Waste and Biomass Valorization, 9(9), pp. 1485-1494, 2018. https://doi.org/10.1007/s12649-017-9953-6

[17] Singh, A., Ganesapillai, M., Gnanasundaram, N. "Optimizaton of extraction of betalain pigments from beta vulgaris peels by microwave pretreatment", In: 14th International Conference on Science, Engineering and Technology (14th ICSET-2017), Vellore, India, IOP Conference Series: Materials Science and Engineering, 263(3), Article number: 032004, 2017. https://oi.org/10.1088/1757-899X/263/3/032004

[18] Ravichandran, K., Saw, N. M. M. T., Mohdaly, A. A. A., Gabr, A. M. M., Kastell, A., Riedel, H., Cai, Z., Knorr, D., Smetanska, I. "Impact of processing of red beet on betalain content and antioxidant activity", Food Research International, 50(2), pp. 670-675, 2013. https://doi.org/10.1016/j.foodres.2011.07.002

[19] Bueno, F. G., Machareth, M. A. D., Panizzon, G. P., Lopes, G. C., Mello, J. C. P., Leite-Mello, E. V. S. "Development of a UV/Vis spectrophotometric method for analysis of total polyphenols from Caesalpinia peltophoroides Benth", Química Nova, 35(4), pp. 822-826, 2012. https://doi.org/10.1590/S0100-40422012000400031

[20] Koczka, N., Stefanovits-Bányai, É., Ombódi, A. "Total Polyphenol Content and Antioxidant Capacity of Rosehips of Some Rosa species", Medicines, 5(3), Article number: 84, 2018. https://doi.org/10.3390/medicines5030084

[21] Benzie, I. F. F., Devaki, M. "The ferric reducing/antioxidant power (FRAP) assay for non-enzymatic antioxidant capacity: concepts, procedures, limitations and applications", In: Apak, R., Capanoglu, E., Shahidi, F. (eds.) Measurement of Antioxidant Activity \& Capacity: Recent Trends and Applications, John Wiley \& Sons Ltd., Hoboken, NJ, USA, 2018, pp. 77-106. https://doi.org/10.1002/9781119135388.ch5

[22] Delgado-Vargas, F., Jimenez, A. R., Paredes-López, O. "Natural Pigments: Carotenoids, Anthocyanins, and Betalains Characteristics, Biosynthesis, Processing, and Stability", Critical Reviews in Food Science and Nutrition, 40(3), pp. 173-289, 2010. https://doi.org/10.1080/10408690091189257 
[23] Tamba, A., Servent, A., Mertz, C., Cissé, M., Dornier, M. "Coupling of pressure-driven membrane technologies for concentrating, purifying and fractionizing betacyanins in cactus pear (Opuntia dillenii Haw.) juice", Innovative Food Science \& Emerging Technologies, 52, pp. 244-255, 2019. https://doi.org/10.1016/j.ifset.2018.12.008

[24] Bucur, L., Țarălungă, G., Schroder, V. "The betalains content and antioxidant capacity of red beet (Beta vulgaris L. subsp. vulgaris) root", Farmacia, 64(2), pp. 198-201, 2016.

[25] Couto, D. S., Corrêa Cabral, L. M., da Matta, V. M., Deliza, R., de Grandi Castro Freitas, D. "Concentration of pineapple juice by reverse osmosis: physicochemical characteristics and consumer acceptance", Food Science and Technology, 31(4), pp. 905-910, 2011. https://doi.org/10.1590/S0101-20612011000400012
[26] Kim, I. C., Jegal, J., Lee, K. H. "Effects of aqueous and organic solutions on the performance of polyamide thin-film composite nanofiltration membranes", Journal of Polymer Science Part B: Polymer Physics, 40(19), pp. 2151-2163, 2002. https://doi.org/10.1002/polb.10265

[27] Zhu, X., Elimelech, M. "Colloidal Fouling of Reverse Osmosis Membranes: Measurements and Fouling Mechanisms", Environmental Science \& Technology, 31(12), pp. 3654-3662, 1997. https://doi.org/10.1021/es970400v 